\title{
Dampak Proteksi Air Susu Ibu Terhadap Infeksi
}

\author{
Omar Sazaly Aldy, Bugis M Lubis, Pertin Sianturi, Emil Azlin, Guslihan D Tjipta \\ Departemen Ilmu Kesehatan Anak, Fakultas Kedokteran, Universitas Sumatera Utara/RSUP H. Adam \\ Malik, Medan
}

\begin{abstract}
Pemberian air susu ibu (ASI) merupakan cara alami untuk menjaga nutrisi yang baik, meningkatkan daya tahan tubuh serta memelihara emosi selama masa pertumbuhan dan perkembangan bayi. ${ }^{1}$ Dilaporkan bahwa ASI mengandung zat nutrisi yang dibutuhkan serta faktor anti bakteri dan anti virus yang melindungi bayi terhadap infeksi. Beberapa penelitian membuktikan ASI dapat mengurangi kejadian berbagai infeksi selama masa bayi dan balita terhadap gastroenteritis, infeksi saluran pernapasan, otitis media, sepsis neonatorum, dan infeksi saluran kemih. (Sari Pediatri 2009;11(3):167-73).
\end{abstract}

Kata kunci: ASI eksklusif, imunitas, infeksi

A ir susu ibu (ASI) sangat diperlukan selama masa pertumbuhan dan perkembangan bayi. ${ }^{1}$ Selain mengandung zat nutrisi yang dibutuhkan, ASI juga meningkatkan daya tahan dan mengandung anti bakteri dan anti virus yang melindungi bayi terhadap infeksi. ${ }^{2,3}$ Dalam laporan WHO disebutkan bahwa hampir 90\% kematian balita terjadi di negara berkembang dan lebih dari $40 \%$ kematian disebabkan diare dan infeksi saluran pernapasan akut, yang dapat dicegah dengan ASI eksklusif. ${ }^{2,4}$

Tahapan sekresi ASI diawali dengan pengeluaran kolostrum pada saat lahir, ASI transisi pada sepuluh hari pertama sampai dua minggu setelah lahir dan

\footnotetext{
Alamat korespondensi

Dr. Bugis M Lubis, SpA. Bagian Ilmu Kesehatan Anak FK USU/RS HAM Jalan Bunga Lau No. 17 Telepon : (061) 8361721, Fax : (061) 8361721 E-mail : bikafkusu@telkom.net; kotak Pos 697 Medan - 20136
}

berikutnya adalah ASI matang. Kandungan dari setiap tahapan berguna untuk bayi baru lahir, terutama upaya adaptasi fisiologis terhadap kehidupan di luar kandungan. Semakin matang ASI, konsentrasi imunoglobulin, total protein dan vitamin yang larut di dalam lemak menurun, sedangkan laktosa, lemak, kalori, dan vitamin yang larut dalam air meningkat. ${ }^{5}$

Pembentukan sistem imun pada manusia dimulai sejak embrio dilanjutkan selama masa fetus dan sempurna dalam beberapa tahun setelah lahir. Fetus tumbuh dalam suatu lingkungan sangat terlindung, bebas kuman, dan kurang berpengalaman terhadap zat antigenik. ${ }^{6}$

Air susu ibu merupakan suatu cairan kompleks dengan sejumlah besar protein, sel, dan komponen lainnya. Pengetahuan tentang dampak menyusui pada bayi terus meningkat, termasuk dampak langsung dan tidak langsung pada sistem imun. Pengaruh imunologis berhubungan dengan kenyataan bahwa ASI kaya dengan berbagai faktor aktif khususnya antibodi. Sekretori $\operatorname{IgA}(\mathrm{sIg} A)$ melindungi membran mukosa 
saluran pencernaan dan pernafasan, antibodi IgG dan IgM, hormon, antioksidan, vitamin, sitokin, faktor pertumbuhan, komponen, prostaglandin, granulosit, makrofag, serta limfosit B dan T.7,8

Beberapa penelitian membuktikan bahwa ASI dapat mengurangi kejadian infeksi selama masa bayi dan balita terhadap gastroenteritis, ${ }^{9-15}$ infeksi saluran pernafasan, ${ }^{9,10,13,14,16}$ otitis media, ${ }^{16,17}$ sepsis neonatorum, ${ }^{9,17}$ dan infeksi saluran kemih. ${ }^{9,14,18}$ Chen dkk menyatakan bahwa bayi yang tidak mendapat ASI, dua kali lebih sering masuk rumah sakit dibandingkan bayi mendapat ASI. ${ }^{19}$ Suatu meta-analisis di negara maju dari bayi dengan penyakit saluran pernafasan berat yang diberi susu formula membutuhkan rawat inap lebih dari tiga kali lipat dibandingkan bayi yang diberi ASI eksklusif 4 bulan atau lebih. ${ }^{20}$

\section{Imunoglobulin pada ASI}

Air susu ibu mengandung imunoglobulin $\mathrm{M}, \mathrm{A}, \mathrm{D}$, G, dan E, namun yang paling banyak adalah sIgA. Sekretori IgA pada ASI merupakan sumber utama imunitas didapat secara pasif selama beberapa minggu sebelum produksi endogen sIgA, konsentrasi paling tinggi pada beberapa hari pertama post partum. ${ }^{21}$ Selama masa pasca lahir, bayi rentan terhadap infeksi patogen yang masuk, oleh sebab itu sIgA adalah faktor protektif penting terhadap infeksi. ${ }^{22,23}$

Studi dari Swedia menyatakan bahwa kadar antibodi IgA dan IgM secara bermakna lebih tinggi pada bayi mendapat ASI dibandingkan yang tidak mendapat ASI. ${ }^{24}$ Imunoglobulin A ( $\operatorname{Ig}$ A) yang terdapat di dalam antibodi maternal didapat dari sistem imun saluran cerna dan pernafasan yang dibawa melalui sirkulasi darah dan limfatik ke kelenjar payudara, akhirnya dikeluarkan melalui ASI sebagai sIgA. ${ }^{22}$

\section{Zat imunologi lain yang dimiliki ASI}

Air susu ibu mempunyai sejumlah faktor yang mempengaruhi mikroflora usus bayi, sehingga menambah kolonisasi dari jumlah bakteri sementara menghambat kolonisasi yang lainnya. Komponenkomponen imunologik ini termasuk,

- Laktoferin, merupakan protein yang terikat dengan zat besi, diproduksi oleh makrofag, neutrofil, dan epitel kelenjar payudara bersifat bakteriostatik dan bakterisid. Menghambat pertumbuhan bakteri dengan cara berikatan dengan zat besi sehingga tidak tersedia untuk bakteri patogen. Kadar dalam ASI $1-6 \mathrm{mg} / \mathrm{ml}$ dan tertinggi pada kolostrum $(600 \mathrm{mg} / \mathrm{dL}) .{ }^{21-23,25,26}$ Laktoferin juga terbukti menghambat pertumbuhan kandida. ${ }^{25}$

- Lisozim, suatu enzim yang diproduksi oleh makrofag, neutrofil, dan epitel kelenjar payudara, dapat memecah dinding sel bakteri Gram positif yang ada pada mukosa usus dan menambah aktifitas bakterisid sIgA terhadap E. coli dan beberapa Salmonella. ${ }^{10,23}$ Kadar dalam ASI 0,1 $\mathrm{mg} / \mathrm{ml}$ yang bertahan sampai tahun kedua laktasi, bahkan sampai penyapihan. Dibandingkan susu sapi, ASI mengandung 300 kali lebih banyak lisozim per satuan volume..$^{21,25}$

- Komplemen, berupa komplemen C3 yang dapat diaktifkan oleh bakteri melalui jalur alternatif sehingga terjadi lisis bakteri. Juga mempunyai sifat opsonisasi sehingga memudahkan fagosit mengeliminasi mikroorganisme pada mukosa usus yang terikat dengan C3 aktif. Kadar C3 dan C4 dalam kolostrum sekitar 50\%-70\% kadar serum dewasa. Pada masa laktasi dua minggu, kadar komplemen menurun dan kemudian menetap, yaitu kadar C3 dan C4 masingmasing $15 \mathrm{mg} / \mathrm{dL}$ dan $10 \mathrm{mg} / \mathrm{dL}^{21,22}$

- Granulocyte colony - stimulating factor (G-CSF) merupakan sitokin spesifik yang dapat menambah pertahanan anti bakteri melalui efek proliferasi, diferensiasi dan ketahanan neutrofil. Mengeluarkan reseptornya dalam vili usus bayi dan kadar meningkat pada dua hari post partum. ${ }^{27}$

- Oligosakarida, menghadang bakteri dengan cara bekerja sebagai reseptor dan mengalihkan bakteri patogen atau toksin mendekat ke faring dan usus bayi. $^{21}$

- Musin, melapisi membran lemak susu dan mempunyai sifat antimikroba, dengan cara mengikat bakteri dan virus serta segera mengeliminasi dari tubuh. Musin dapat menghambat adhesi E.coli dan rotavirus. Disamping itu ASI mengandung enzim PAF-hidrolase yang dapat memecah PAF yang berperan pada enterokolitis nekrotikans. Lactadherin protein globule fat pada ASI dapat merusak membran pembungkus virus. Kvistgaard $\mathrm{dkk}^{28}$ mendapatkan bahwa PAF-hidrolase dapat melindungi bayi dari infeksi Rotavirus.

- Lipase, membentuk asam lemak dan monogliserida yang menginaktivasi organisme, sangat efektif terhadap Giardia lamblia dan Entamoeba histolytica. ${ }^{21,22}$ 
- Interferon dan fibronektin mempunyai aktifitas antiviral dan menambah sifat lisis dari leukosit susu. $^{22}$

- Protein pengikat vitamin B12 dan asam folat, dapat menjadi antibakteri dengan menghalangi bakteri seperti E.coli dan bacteroides untuk mengikat vitamin bebas sebagai faktor pertumbuhan..$^{23,29}$

- Probiotik, bayi yang mendapat ASI mempunyai kandungan Lactobacilli yang tinggi, terutama Lactobacillus bifidus (Bifidobacterium bifidum). Glikan merupakan komponen ASI yang menstimulasi pert umbuhan dan kolonisasi L. bifidus. ${ }^{22}$ Kuman ini akan mengubah laktosa menjadi asam laktat dan asam asetat, situasi asam dalam cairan usus akan menghambat pertumbuhan E. Coli. ${ }^{25}$

Tabel 1. Faktor pertahanan tubuh sistem gastrointestinal di dalam ASI

\begin{tabular}{lcc}
\hline & \multicolumn{2}{c}{ Sasaran gastrointestinal } \\
Zat dalam ASI & Epitel & Sistem imun \\
\hline IGF-1 & + & - \\
Poliaminase & + & - \\
TGF & + & + \\
Laktoferin & + & + \\
Prolaktin & + & + \\
TNF- $\alpha$ & + & + \\
IL-6 & - & + \\
IL-10 & - & + \\
VIP & - & + \\
Zat P & - & + \\
Somatostatin & - & + \\
\hline
\end{tabular}

IGF-1 : insulin-like growth factor 1; TGF: transforming growth factor; TNF- $\alpha$ : tumor necrosis factor $\alpha$; IL: interleukin; VIP: vasoactive peptide

\section{Sel yang terdapat pada ASI}

Leukosit (90\% dari jumlah sel) di dalam ASI terutama terdiri dari makrofag (90\%). Sel makrofag ASI merupakan sel fagosit aktif sehingga dapat menghambat multiplikasi bakteri pada infeksi mukosa usus. Selain sifat fagositik, sel makrofag juga memproduksi lisozim, C3 dan C4, laktoferin, monokin seperti IL-1 serta enzim lainnya. Makrofag ASI dapat mencegah enterokolitis nekrotikans pada bayi. Limfosit (10\% dari jumlah sel) $50 \%$ terdiri atas limfosit $\mathrm{T}$ dan $34 \%$ limfosit $\mathrm{B}$. Fungsi limfosit untuk mensintesis antibodi IgA, memberikan respons terhadap mitogen dengan cara berproliferasi, meningkatkan interaksi makrofag - limfosit dan pelepasan mediator. ${ }^{28}$ Leukosit ASI dapat bertahan terhadap perubahan $\mathrm{pH}$, suhu dan osmolaritas, sama dengan yang terjadi pada binatang bertahan selama seminggu pada orang utan dan domba. ${ }^{21-23}$

\section{Imunitas pasif dari ibu}

Sementara menunggu sistem imunologi endogen bayi matang, berbagai komponen imunologi dan bioaktif susu bekerja secara sinergis untuk memberikan sistem penyokong imunologi pasif dari ibu ke bayinya pada hari dan bulan pertama kelahiran. Beberapa studi secara jelas mengatakan keuntungan secara klinis menunjukkan penurunan risiko infeksi saluran cerna dan pernapasan terutama selama tahun pertama kehidupan. ${ }^{21}$ Kejadian meningkatnya faktor bioaktif dan imun dapat menjelaskan penurunan risiko alergi saluran cerna dan pernapasan serta penyakit autoimun pada anak yang diberi ASI. 22,30

Kegunaan faktor-faktor yang terkandung di dalam ASI tertera pada Tabel 1, 2, 3, dan $4 . .^{30}$

Tabel 2. Faktor anti parasit yang terdapat di dalam ASI

\begin{tabular}{ll}
\hline Faktor & Secara in vitro aktif terhadap \\
\hline I IgA sekretorik & Giardia lamblia, Entamoeba histolytica, Schistosoma \\
& mansoni (blood fluke), Cryptosporidium, Toxoplasma \\
& gondii, Plasmodium falciparum \\
I IgG & Plasmodium falciparum \\
Gangliosida & Giardia lamblia, Giardia muris \\
Lipid (asam lemak bebas dan monogliserida) & Giardia lamblia, Entamoeba histolytica, Trichomonas \\
& vaginalis, Eimeria tenella (animal coccidiosis) \\
Laktoferin (atau pepsin-generasi laktoferisin) & Giardia lamblia, Plasmodium falciparum \\
Tidak teridentifikasi & Trypanosoma brucei rhodesiense \\
Makrofag & Entamoeba histolytica \\
\hline
\end{tabular}


Tabel 3. Faktor anti bakteri yang terdapat di dalam ASI

\begin{tabular}{|c|c|}
\hline Faktor & Secara in vitro aktif terhadap \\
\hline IgA sekretorik & $\begin{array}{l}\text { E. coli (juga antigen pili, kapsul, CFA1) termasuk strain } \\
\text { enteropatogenik, C. tetani, C. diphtheriae, K. pneumoniae, S. pyogenes, } \\
\text { S. mutans, S. sanguins, S. mitis, S. agalactiae (group B streptococci), } \\
\text { S. salvarius, S. pneumoniae (juga polisakarida kapsul), C. burnetti, } \\
\text { H. influenzae. H. pylori, S. flexneri, S. boydii, S. sonnei, C. jejuni, N. } \\
\text { meningitidis, B. pertussis, S. dysenteriae, C. trachomatis, Salmonella (6 } \\
\text { group), S. minnesota, P. aeruginosa, L. innocua, Campylobacter flagelin, } \\
\text { Y. enterocolitica, S. flexneri virulence plasmid antigen, C. diphtheriae } \\
\text { toksin, E. coli enterotoxin, V. cholerae, enterotoksin C. diffcile toksin, } \\
\text { kapsul H. influenzae, S. enterotoksin F aureus, Candida albicans*, } \\
\text { Mycoplasma pneumoniae }\end{array}$ \\
\hline IgG & $\begin{array}{l}\text { E. coli, B. pertussis, H. influenzae tipe b, S. pneumoniae, S. agalactiae, } \\
\text { N. meningitidis, } 14 \text { pneumoccoccal capsular polysaccharides, V. cholerae } \\
\text { lipopolysaccharide, S. flexneri invasion plasmid-coded antigens, major } \\
\text { opsonin for S. aureus }\end{array}$ \\
\hline $\operatorname{IgM}$ & V. cholerae lipopolysaccharide, E. coli, S. flexneri \\
\hline $\mathrm{IgD}$ & E. coli \\
\hline $\begin{array}{l}\text { Analog reseptor sel epitelial (oligosakarida dan } \\
\text { sialylated oligosaccharides }{ }^{* * *} \text { ) }\end{array}$ & S. pneumoniae, H. influenzae \\
\hline $\begin{array}{l}\text { Bifidobacterium bifidum growth factors } \\
\text { (oligosakarida, glikopeptida) } \\
\text { Bifidobacteria growth factors lainnya (alpha- } \\
\text { lactoglobulin, lactoferrin, sialyllactose) }\end{array}$ & $\begin{array}{l}\text { Bakteri enterik. Bifidobacteria species menghasilkan molekul lipofilik } \\
\text { yang dapat membunuh S. typhimurium. B. bifidum memproduksi } \\
\text { Bifidocin B yang dapat membunuh Listeria. B. longum memproduksi } \\
\text { protein BIF, yang menghentikan E. coli. }\end{array}$ \\
\hline Karbohidrat & Enterotoksin E. coli, E. coli, C. diffcile toksin A \\
\hline Cathelicidin (LL-37 peptide) & S. aureus, group A streptococcus, E. coli \\
\hline Kasein & H. influenzae \\
\hline kappa-kasein** & H. pylori, S. pneumoniae, H. influenzae \\
\hline Komplemen C1-C9 (mainly C3 dan C4) & Membunuh S. aureus in macrophages, E. coli (serum-sensitive) \\
\hline $\begin{array}{l}\text { B-defensin- } 1 \text { atau }-2 \text { atau neutrofil- } \alpha \text {-defensin- } 1 \\
\text { atau } \alpha \text {-defensin- } 5 \text { atau }-6\end{array}$ & E. coli, $P$. aeruginosa, (beberapa Candida albicans ${ }^{*}$ ) \\
\hline Faktor binding proteins (zinc, vitamin B12, folate) & Dependent E. coli \\
\hline Free secretory component ${ }^{* *}$ & $\begin{array}{l}\text { E. coli colonization factor antigen } 1 \text { (CFA I) dan CFA II, toksin } \\
\text { C. difficile A, H. pylori, E. coli }\end{array}$ \\
\hline Fucosylated oligosaccharides & E. coli heat stable enterotoxin, C. jejuni, E. coli \\
\hline Gangliosid GM1 & Enterotoksin E. coli, toksin V. cholerae, enterotoksin C. jejuni, E. coli \\
\hline Gangliosid GM3 & E. coli \\
\hline Glikolipid Gb3 & S. dysenterae toksin, shigatoxin shigella dan E. coli \\
\hline Glikoprotein (mannosylated) & E. coli, E. coli CFA11, fimbrae \\
\hline Glikoprotein (receptor-like)+ oligosakarida & V. cholerae \\
\hline $\begin{array}{l}\text { Glikoprotein (berisi sialic acid atau galaktosa } \\
\text { terminal) }\end{array}$ & E. coli (S-fimbrinated) \\
\hline Aalpha-laktalbumin (variant) & S. pneumoniae \\
\hline Lactoferrin** & $\begin{array}{l}\text { E. coli, E. coli/CFA1 or S-fimbriae, Candida albicans *, Candida } \\
\text { krusei }^{*} \text {, Rhodotorula rubra* } \\
\text { actinomycetemcomitans }\end{array}$ \\
\hline
\end{tabular}


Omar Sazaly Aldy dkk: Dampak proteksi ASI terhadap infeksi

\begin{tabular}{|c|c|}
\hline Faktor & Secara in vitro aktif terhadap \\
\hline Laktoperoksidase & Streptococcus, Pseudomonas, E. coli, S. typhimurium \\
\hline Antigen Lewis & S. aureus, C. perfringens \\
\hline Lipid & $\begin{array}{l}\text { S. aureus, E. coli, S. epidermis, } H . \text { influenzae, S. agalactiae, } L . \\
\text { monocytogenes, } N . \text { gonorrhoeae, } C \text {. trachomatis, B. parapertusis heat- } \\
\text { labile toxin, mengikat Shigella-like toxin-1 }\end{array}$ \\
\hline Lisozim & $\begin{array}{l}\text { E. coli, Salmonella, M. lysodeikticus, S. aureus, P. fragi, growing } \\
\text { Candida albicans* dan Aspergillus fumigatus* }\end{array}$ \\
\hline $\begin{array}{l}\text { Sel ASI ( } 80 \% \text { makrofag, } 15 \% \text { neutrofil, } 0.3 \% \\
\text { limfosit B dan } 4 \% \text { limfosit T) }\end{array}$ & $\begin{array}{l}\text { Dengan fagositosis dan membunuh: E. coli, } S \text {. aureus, } S \text {. enteritidis } \\
\text { Dengan mensensitisasi limfosit: E. coli } \\
\text { Dengan fagositosis: Candida albicans }{ }^{*} \text { E. coli } \\
\text { stimulasi limfosit: } E \text {. coli K antigen, tuberkulin } \\
\text { Spontaneous monokines: terstimulasi oleh lipopolisakarida } \\
\text { Menginduksi sitokin: PHA, PMA + ionomycin } \\
\text { Fibronektin membantu asupan oleh sel fagositik }\end{array}$ \\
\hline Musin (muc-1; membran globulin lemak ASI) & E. coli (S-fimbrinated) \\
\hline Nonimmunoglobulin (lemak ASI, protein) & C. trachomatis, $Y$. enterocolitica \\
\hline Fosfatidiletanolamin & H. pylori \\
\hline (Tri sampai penta) phosphorylated beta-casein & H. influenzae \\
\hline Sialyllactose & Toksin V. cholerae, H. pylori \\
\hline Sialyloligosaccharides pada $\operatorname{sigA}(\mathrm{Fc})$ & Adhesi E. coli (S-fimbrinated) \\
\hline Soluble bacterial pattern recognition receptor $\mathrm{CD} 14$ & $\begin{array}{l}\text { Bakteri (atau LPS) mengaktivasi untuk induksi molekul respons imun } \\
\text { dari sel usus }\end{array}$ \\
\hline Sulphatide (sulphogalactosylceramide) & S. typhimurium \\
\hline Faktor yang tidak teridentifikasi & $\begin{array}{l}\text { S. aureus, B. pertussis, C. jejuni, E. coli, S. typhimurium, S. flexneri, S. } \\
\text { sonnei, V. cholerae, L. pomona, L. hyos, L. icterohaemorrhagiae, toksin B } \\
\text { C. difficile, H. pylori, C. trachomatis }\end{array}$ \\
\hline Xanthine oxidase (dengan tambahan hipoxantin) & E. coli, S. enteritidis \\
\hline $\begin{array}{l}\text { Faktor yang ditemukan pada kadar sangat rendah } \\
\text { dalam ASI }\end{array}$ & Secara invitro aktif terhadap \\
\hline CCL28 (CC-chemokine) & $\begin{array}{l}\text { Candida albicans*, P. aeruginosa, S. mutans, S. pyogenes, S. aureus, } K \text {. } \\
\text { pneumonidae }\end{array}$ \\
\hline Heparin & Chlamydia pneumoniae \\
\hline RANTES (CC-chemokine) & E. coli, S. aureus, Candida albicans*, Cryptococcus neoformans* \\
\hline $\begin{array}{l}\text { Secretory leukocyte protease inhibitor (protease } \\
\text { antileukosit; SLPI) }\end{array}$ & E. coli, S. aureus, growing C. albicans ${ }^{*}$ dan A. fumigatus ${ }^{*}$ \\
\hline
\end{tabular}

\section{Ringkasan}

Hampir 90\% kematian balita terjadi di negara berkembang dan lebih dari $40 \%$ kematian disebabkan diare dan infeksi saluran pernapasan akut. Penyakit saluran cerna dan saluran nafas dapat dicegah dengan ASI eksklusif, oleh karena ASI kaya mengandung berbagai faktor aktif imunologis khususnya antibodi. 


\section{Daftar Pustaka}

1. American Academy of Pediatrics. Section on breastfeeding. Policy statement. breastfeeding and the use of human milk. Pediatrics 2005;115:496-506.

2. Kramer MS, Kakuma R. The optimal duration of exclusive breast-feeding a systematic review. Geneva: World Health Organization; document WHO/ NHD/01.08/FCH/CAH/01.23, 2001.

3. Heikkilä MP, Saris PEJ. Inhibition of Staphylococcus aureus by the commensal bacteria of human milk. J of App Microb 2003;95:471-8.

4. Leon-Cava N, Lutter C, Ross J, Martin L. Quantifying the benefits of breastfeeding: a summary of the evidence. The Linkages Project. Washington DC: Pan American Health Organisation; 2002. Didapat dari: www.aed.org/ ToolsandPublications/upload/quantifyingbenefits.pdf.

5. Lawrence RA, Lawrence RM. Biochemistry of human milk. Dalam: Lawrence RA, Lawrence RM, penyunting. Breastfeeding. A guide for the medical profession. Edisi ke - 6. Philadelphia: Elsevier Mosby; 2005.h.105-70.

6. Chirico G, Gasparoni A. Immunologic components of human milk. Haematologica reports 2006;2:27-30.

7. Hanson LA, Wiedermann U, Ashraf R. Effects of breastfeeding on the baby and on its immune system. Food and nutrition bulletin 1996;17:384-9.

8. Adkins Y, Lonnerdal B. Potential host-defense role of a human milk vitamin B-12-binding protein, haptocorrinn, in the gastrointestinal tract of breastfed infants, as assessed with porcine haptocorrin in vitro. Am J Clin Nutr 2003; 77:1234-40.

9. Kramer MS. Infant feeding, infection and public health. Pediatrics 1988;81:164-6.

10. Ogundele MO. Complement-mediated bactericidal activity of human milk to a serum-susceptible strain of E.coli 0111. J of App Microb 1999;87:689-96.

11. Kovar MG, Serdula MK, Marks JS. Review of the epidemiologic evidence for an association between infant feeding and infant health. Pediatrics 1984;74: S61538.

12. Popkin BM, Adair L, Akin JS. Breast-feeding and diarrheal morbidity. Pediatrics 1990;86:874-82.

13. Arifeen S, Black RE, Antelman G. Exclusive breastfeeding reduce acute respiratory infection and diarrhea deaths among infants in Dhaka slums. Pediatrics 2001; 108:1-8.

14. Allen J. Benefits of breastfeeding. NSW Public Health Bull 2005; 16: 42-6.

15. Kramer S, Chalmers B. Promotion of breastfeeding intervention trial (PROBIT) a randomized trial in the republic of Belarus. JAMA 2001; 285: 413-20.

16. Frank AL, Taber LH, Glezen WP. Breast-feeding and respiratory virus infection. Pediatrics 1982; 70:239-45.

17. Paradise JL, Elster BA, Tan L. Evidence in infants with cleft palate that breast milk protects against otitis media. Pediatrics 1994;94:853-60.

18. Bonuck KA, Freeman K. Trombley M. Randomized controlled trial of a prenatal and postnatal lactation consultant intervention on infant health care use. Arch Pediatr Adolesc Med 2006;160:953-60.

19. Chen Y, Yu S, Li WX. Artificial feeding and hospitalization in the first 18 months of life. Pediatrics 1988;81:58-62.

20. Bachrach VRG, Schwarz E, Bachrach LR. Breastfeeding and the risk of hospitalization for respiratory disease in infancy: A meta-analysis. Arch Pediatr Adolesc Med 2003; 157:237-43.

21. Matondang CS. Aspek imunologi air susu ibu. Dalam: Akib AAP, Munasir Z, Kurniati N, penyunting. Buku ajar alergi-imunologi anak. Edisi ke-2. Jakarta: IDAI; 2007. h.190-204.

22. Wagner CL. Human milk and lactation. Didapat dari : http://www.emedicine.com

23. Fewtrel M, Lucas A. Feeding the full-term infant. Dalam: Rennie JM, penyunting. Roberton's textbook of neonatology. Edisi ke-4. London: Churchill livingstone; 2005.h.302-13.

24. Butte NF, Alarcon MGL, Garza C. Nutrient adequacy of exclusive breastfeeding for the term infant during the first six months of life. Geneva; World Health Organization: document WHO 2002.

25. Lubis CP. Peranan air susu ibu dalam mencegah diare dan penyakit usus lainnya. USU digital library 2003;1-4.

26. Lawrence RA, Lawrence RM. Host - resistance factors and imunologic significance of human milk. Dalam: Lawrence RA, Lawrence RM, penyunting. Breastfeeding. A guide for the medical profession. Edisi ke-6. Philadelphia; Elsevier Mosby, 2005.h.171-214.

27. Calhoun DA, Lunoe M, Du Y, Christensen RD. Granulocyte colony - stimulating factor is present in human milk and its reseptor is present in human fetal intestine. Pediatrics 2000;105:1-6.

28. Kvistgaard AS, Pallesen LT, Arias CF. Inhibitory effects of human and bovine milk constituents on rotavirus infections. J Dairy Sci 2004;87:4088-96.

29. Suradi R. Peran air susu ibu dalam mencegah infeksi pada neonatus. Dalam: Hegar B, Trihono PP, Ifran EB, penyunting. Update in neonatal infection. PKB-FKUI 
Omar Sazaly Aldy dkk: Dampak proteksi ASI terhadap infeksi

Jakarta; 2005.h.59-73.

30. Goldman AS. Modulation of the gastrointestinal tract of infants by human milk. Interfaces and interactions. An evolutionary perspective. J Nutr 2000; 130: 426S-31S. 